\title{
ОЦЕНКА ГЕНЕТИЧЕСКОГО РАЗНООБРАЗИЯ ОБРАЗЦОВ КАПУСТЫ КОЧАННОЙ (Brassica oleracea L.) С ИСПОЛЬЗОВАНИЕМ SSR MAPKEPOB
}

\author{
А.С. ДОМБЛИДЕС ${ }^{凶}$, Л.Л. БОНДАРЕВА, В.Ф. ПИВОВАРОВ
}

Из всех разновидностей капусты в Российской Федерации наиболее распространены традиционные сорта и гибриды капусты кочанной Brassica oleracea L. convar. capitata (L.). Классификация селекционного материала с использованием ДНК маркеров позволяет выделить ценные генотипы и установить между ними генетические взаимосвязи для последующей селекции на генетически отличимые формы. Микросателлитные маркеры (simple sequence repeats, SSR) широко используют для генетической идентификации и генотипирования сельскохозяйственных культур. Работы на B. oleracea L. показали их высокую эффективность по выявлению полиморфизма между разновидностями, сортами и внутри сортов. В настоящем исследовании мы впервые установили генетические взаимосвязи между селекционными образцами капусты кочанной отечественной селекции на основе полиморфизма микросателлитных локусов. При сравнении трех разновидностей обнаружена тесная генетическая близость между генотипами савойской и белокочанной капусты. Целью работы было выявление генетических взаимоотношений между селекционными образцами Brassica oleracea L. convar. capitata (L.) Alef. var. capitata L. f. alba, var. capitata L. f. rubra и var. sabauda L. на основе типирования и генетической классификации с помощью SSR маркеров, a также сопоставление данных ДНК-анализа с принадлежностью изученных генотипов к соответствующими сортотипам и группами спелости. Объектом исследования были 24 селекционных образца капусты кочанной из коллекции Федерального научного центра овощеводства (ФГБНУ ФНЦО), включая краснокочанную и савойскую разновидности, выведенные в ФГБНУ ФНЦО. Геномную ДНК выделяли из молодых листьев растений в фазу 2-3-го листа с использованием набора реагентов Сорб-ГМО-Б (ООО «Синтол», Россия). Для оценки чистоты и концентрации выделенной ДНК использовали спектрофотометр SmartSpec Plus («Bio-Rad», США). Для осуществления SSR-анализа отобрали 21 микросателлитный локус с известными последовательностями праймеров. Амплификацию осуществляли на приборе C1000 Touch («Bio-Rad», CШA). ПЦР-продукты разделяли методом вертикального электрофореза с использованием системы SequiGen GT («Bio-Rad», CША) в 6 \% полиакриламидном секвенирующем геле. Размеры амплифицированных фрагментов определяли в сравнении с маркером молекулярных масc GeneRuler100 bp plus DNA ladder («Thermo Fisher Scientific», США). Полученные цифровые фотографии электрофореграмм анализировали в программе Image Lab 3.0 («Bio-Rad», CША). Структуру популяции изучали в программе STRUCTURE 2.3.4 (https://web.stanford.edu/group/pritchardlab/home.html). Расчет генетических расстояний проводили в программе GenAlEx 6.5 для Microsoft Excel по методу М. Nei. Для построения UPGMA дендрограммы использовали алгоритм программы MEGA5.2. В результате анализа получили 103 аллеля со средним показателем 4,9 на локус. Размеры продуктов амплификации составляли 130-410 п.н. Величина информационного полиморфизма (PIC) для праймеров варьировала от 0,3 до 0,9. Анализ популяции выявил, что все образцы распределились по шести основным кластерам. Генетические дистанции варьировали от 0,060 до 0,186. Дендрограмма UPGMA, построенная на основе генетических дистанций, отражала происхождение исследуемых селекционных образцов. Так, сорта Белорусская 455, Подарок 2500, Амагер 611 и Зимовка 1474 с происхождением из Северо-Западной Европы, были объединены в общий кластер, где также находился гибрид Северянка F1, созданный с использованием этих сортов. Сорта, принадлежащие к сортотипу Дитмарская ранняя, - Июньская 3200, Стахановка 1513, Номер первый грибовский 147 образовали отдельный кластер, куда также входил раннеспелый гибрид Аврора F1, имеющий в своей родословной сорт Июньская 3200. Две селекционные линии, выделенные из гибрида Аврора F1, были генетически отдалены и располагались в другом подкластере. Сорта Слава 1305 и Слава грибовская 231, относящиеся к отдельному сортотипу Слава, располагались на отдельной ветви дендрограммы. Относительно недавно полученные сорт Парус и два гибрида Зарница F1 и Мечта F1 генетически отличались от остальных образцов. Московская поздняя 15, стародавний сорт местного происхождения, также образовал отдельную ветвь дендрограммы. Три сорта капусты савойской сгруппировались вместе, причем новый раннеспелый сорт Московская кружевница был генетически отдален от двух других. Образцы капусты краснокочанной образовывали свою группу с достаточным генетическим отдалением между образцами. Полученные результаты на основе изменчивости SSR локусов совпадали с данными о происхождении образцов капусты кочанной, подтверждая их принадлежность к определенным сортотипам и группам спелости, что позволит использовать этот селекционный материал в дальнейшем для получения новых форм.

Ключевые слова: Brassica oleracea L., капуста кочанная, SSR маркеры, генетическая 
Китай, Индия и Российская Федерация - основные производители капусты в мире, причем Россия оставляет за собой лидерство в ее потреблении (1). Капуста обладает антиоксидантными свойствами благодаря содержанию полифенолов, антоцианов, галловой, ванилиновой и кумаровой кислот. В ее биохимический состав входят такие антивоспалительные вещества, как глутамин и флавоноиды. Капуста также служит прекрасным источников витамина С и глюкозинолатов (2).

Из вида Brassica oleracea L. (CC, $2 n=18)$ наиболее известна капуста белокочанная B. oleracea L. convar. capitata L. Alef. var. capitata (L.) f. alba DC. как наиболее употребляемая в России. В меньшей степени известны краснокочанная $B$. oleracea L. convar. capitata (L.) Alef. var. capitata (L.) f. rubra (L.) Thell., савойская B. oleracea L. convar. capitata (L.) Alef. var. sabauda L., цветная B. oleracea L. convar. botrytis (L.) Alef. var. botrytis L., брокколи B. oleracea L. convar. botrytis (L.) Alef. var. italica Plenck, брюссельская B. oleracea L. convar. gemmifera (DC.) Gladis var. gemmifera DC., кольраби B. oleracea L. convar. acephala (DC.) Alef. var. gongylodes L. и декоративная листовая B. oleracea L. convar. acephala (DC.) Alef. var. sabellica L. Сорта и высокопродуктивные гибриды - ожидаемый результат селекционной работы с видом $B$. oleracea L. Отличительная особенность кочанных капуст convar. capitata - наличие форм с наиболее длительным периодом яровизации и морозоустойчивостью. Первоначальное формирование биоразнообразия капусты кочанной происходило в Западном Средиземноморье, а также в Западной и Северной Европе, откуда она распространилась в Восточную Европу, Америку, страны Азии (Китай, Япония), Австралию и Африку. Ее широкому распространению способствовали такие свойства, как высокая урожайность и транспортабельность. Капуста кочанная характеризуется значительным сортовым разнообразием по скороспелости, не требовательна к теплу, обладает положительной реакцией на длинный световой день и отзывчива на применение технологий возделывания, позволяющих увеличить период вегетации (3).

Для рационального использования генетических ресурсов и получения новых форм с высоким показателем гетерозиса и стабильности проявления хозяйственно ценных признаков необходимо знать генетическую основу используемого материала. Кроме того, с появлением нового селекционного материала нужно различать все генотипы и идентифицировать среди них одинаковые или близкородственные. Использование ДНК маркеров на основе микросателлитных повторов (simple sequence repeats, SSR) облегчает задачу точной генетической классификации селекционных образцов. Преимущества микросателлитных маркеров над другими заключаются в надежности и выявлении высокого генетического полиморфизма, что делает их наиболее популярными и универсальными в генетических исследованиях сельскохозяйственных культур (4-6).

Накопление информации по изменчивости микросателлитных локусов привело к созданию базы данных, где общее количество микросателлитных маркеров для видов рода Brassica L., включая B. oleracea, достигало 398 (7). С использованием этих данных были установлены и подтверждены генетические взаимосвязи между видами рода Brassica (8-10). Проведен генетический анализ внутри вида B. oleracea и получены сведения о взаимосвязях как между разновидностями капусты, так и среди сортов и селекционных линий (11-14). Филогенетические исследования вида B. oleracea также проводили на основе изменчивости микросателлитов (15). Коллек- 
цию из 91 коммерческого образца капусты белокочанной проанализировали по 69 микросателлитным маркерам, которые выявили 359 аллелей, разделенных на 6 кластеров. В первые два входили генотипы капусты белокочанной, в остальные - генотипы разновидностей брокколи, цветной, кольраби и листовой капусты (16). Среди различных селекционных образцов капусты белокочанной была определена высокая генетическая изменчивость с возможностью точного типирования каждого растения на основе полиморфизма микросателлитов (17).

Обобщая результаты предыдущих исследований, нужно отметить, что число работ по изучению генетического разнообразия традиционных отечественных сортов и гибридов капусты кочанной ограничено. Сорта, выведенные и районированные с участием Е.М. Поповой еще в 1940-х годах на Грибовской опытной станции, и сегодня используются как исходный селекционный материал для получения новых форм.

В настоящей работе мы впервые установили генетические взаимосвязи между селекционными образцами капусты кочанной отечественной селекции на основе полиморфизма микросателлитных локусов. При сравнении трех разновидностей обнаружена тесная генетическая близость между генотипами савойской и белокочанной капусты.

Нашей целью было выявление генетических взаимоотношений между селекционными образцами Brassica oleracea L. convar. capitata (L.) Alef. var. capitata L. f. alba, var. capitata L. f. rubra и var. sabauda L. на основе типирования и генетической классификации с помощью SSR маркеров, а также сопоставление данные ДНК-анализа с принадлежностью изученных генотипов к соответствующими сортотипам и группами спелости.

Методика. Объектом исследования были 24 селекционных образца капусты кочанной из генетической коллекции (Уникальная научная установка, ВНИИССОК) Федерального научного центра овощеводства (ФГБНУ ФНЦО). Геномную ДНК выделяли из молодых листьев растений в фазу 23-го листа методом на основе СТАВ буфера с использованием набора реагентов Сорб-ГМО-Б (ООО «Синтол», Россия) согласно прилагаемому протоколу производителя. Перед выделением ткань молодых листочков (от пяти растений каждого образца) подвергали гомогенизации в экстракционном буфере на приборе TissueLyser II («Qiagen», Германия) (частота 26 Гц, 1560 колебаний/мин, продолжительность 1,7 мин). Конечную чистоту и концентрацию выделенной ДНК определяли на спектрофотометре SmartSpec Plus («Bio-Rad», США). Для проведения амплификации использовали растворы ДНК с ОD $260 / 280=1,6-1,8$.

Для осуществления SSR-анализа был отобран 21 микросателлитный локус с известными последовательностями праймеров $(11,12)$, которые в предыдущих исследованиях показывали значения PIC (polymorphism information content, величина информационного полиморфизма) не менее 0,5. Базовую постановку ПЦР проводили в реакционной смеси (объем 25 мкл), которая включала 2,5 мкл 10× ПЦР буфера, 2,5 мМ $\mathrm{MgCl}_{2}, 0,25$ мМ каждого dNTP, 0,3 мкM каждого праймера, 1,5 ед. Таq ДНК-полимеразы (OOO «Синтол», Россия) и 3 мкл ДНК каждого исследуемого образца. Основной протокол амплификации включал следующие этапы: 45 с при 92-95 ${ }^{\circ} \mathrm{C}$ (денатурация), 30 с при температуре от 52 до $58^{\circ} \mathrm{C}$ в зависимости от пары праймеров (отжиг), от 30 с до 1 мин при $72{ }^{\circ} \mathrm{C}$ (элонгация). Амплификацию, рассчитанную на 35 циклов, осуществляли на приборе C1000 Touch («Bio-Rad», США).

ПЦР-продукты разделяли методом вертикального электрофореза с использованием системы Sequi-Gen GT («Bio-Rad», США) в 6 \% поли- 
акриламидном секвенирующем геле при напряжении 1600 В в течение 1,52 ч. После электрофореза гели окрашивали красителем для гелей SYBR ${ }^{\mathrm{TM}}$ Safe DNA Gel Stain («Invitrogen», США), результаты документировали с использованием системы ChemiDoc XRS+ («Bio-Rad», США). Размеры амплифицированных фрагментов определяли в сравнении с маркером молекулярных масс GeneRuler100 bp plus DNA ladder («Thermo Fisher Scientific», США). Полученные цифровые фотографии электрофореграмм анализировали в программе Image Lab 3.0 («Bio-Rad», США).

Для каждого SSR-локуса учитывали присутствие и отсутствие продукта (соответственно 1 и 0) для составления итоговой бинарной матрицы. Для каждого праймера рассчитывали значение PIC (18). Структуру популяции изучали в программе STRUCTURE 2.3.4 (http://web.stanford.edu/group/pritchardlab/home.html) (18), для определения значения $\Delta \mathrm{K}$ использовали программy STRUCTURE HARVESTER v0.6.1 (http://taylor0.biology.ucla.edu/structureHarvester/) (20). Анализ данных в STRUCTURE не предусматривал информации о числе кластеров, поэтому их вероятное число определяли от 1 до 12 с последующим сравнением К для каждого из вариантов. Генетические расстояния рассчитывали в программе GenAlEx 6.5 (https://biologyassets.anu.edu.au/GenAlEx/Download.html) (21) для Microsoft Excel по методу M. Nei $(22,23)$. Для построения UPGMA дендрограммы использовали алгоритм программы MEGA5.2 (https://mega.software.informer.com/5.2/) (24).

Результаты. Изученные образцы и разновидности капусты кочанной приведены в таблице 1, характеристики полиморфных микросателлитных локусов для вида $B$. oleracea, использованных в работе, указаны в таблице 2.

\section{1. Селекционные образцы, отобранные для оценки генетического разнообразия капусты кочанной (Brassica oleracea L.) с использованием SSR маркеров (кол- лекция ФГБНУ Федерального научного центра овощеводства)}

\begin{tabular}{|c|c|c|}
\hline Название & Сортотип & Обозначение \\
\hline \multicolumn{3}{|c|}{ О б р а з ц ы convar. capitata (L.) Alef. var. capitata L. f. alba DC } \\
\hline Амагер 611 & Амагер & Ama \\
\hline Аврора $\mathrm{F}_{1}$ & Дитмарская ранняя & Avr \\
\hline Аврора $\mathrm{F}_{1}$ линия 1 & Дитмарская ранняя & AvL1 \\
\hline Аврора $\mathrm{F}_{1}$ линия 2 & Дитмарская ранняя & AvL2 \\
\hline Белорусская 455 & Белорусская & Bel \\
\hline Зарница F1 & Дитмарская ранняя & Zar \\
\hline Зимовка 1474 & Лангендейская зимняя & Zim \\
\hline Июньская 3200 & Дитмарская ранняя & Iju \\
\hline Московская поздняя 15/репродукция & Московская поздняя & MoPo/MoPol \\
\hline Мечта $F_{1}$ & Лангендейская зимняя & Mech \\
\hline Номер первый грибовский 147 & Дитмарская ранняя & N1 \\
\hline Парус/репродукция & Голландская группа & Par/Par4 \\
\hline Подарок 2500 & Белорусская & Pod \\
\hline Северянка $\mathrm{F}_{1}$ & Белорусская & Sev \\
\hline Слава 1305 & Слава & $\mathrm{S} 113$ \\
\hline Слава грибовская 231 & Слава & $\mathrm{S} 123$ \\
\hline Стахановка 1513 & Дитмарская ранняя & Sta \\
\hline \multicolumn{3}{|c|}{ О б р а 3 ц } \\
\hline Вертю 1340 & Вертю & Ver \\
\hline Московская кружевница & Розеточная & MosKr \\
\hline Юбилейная 2170 & Ульмская & Ubi \\
\hline \multicolumn{3}{|c|}{ О б р а 3 ц ы var. capitata L. f. rubra } \\
\hline Гако 741 & Гако & Gak \\
\hline Каменная головка 447 & Эрфуртская & $\mathrm{KamG}$ \\
\hline Рубин & Турновская & Rub \\
\hline Краснокочанная линия I3 & Эрфуртская & RedL1 \\
\hline
\end{tabular}

При амплификации 21 микросателлитного локуса было получено 103 аллеля со средним числом 4,9 для каждого локуса. При этом для изученных образцов выявили 13 специфичных аллелей. Наибольшее число специфичных аллелей (семь) было найдено у образцов Северянка F1, Бело- 
русская 455, Подарок 2500, Амагер 611 и Зимовка 1474. Размеры продуктов амплификации варьировали от 130 до 410 п.н. Наиболее информативные SSR-локусы AF458409 и BZ523957 с индексом информативности для праймеров соответственно 0,90 и 0,86 были представлены пятью аллелями (рис. 1). Однако менее информативные SSR-локусы с PIC праймеров 0,69 могли содержать большое число аллелей - до 13, как у СС969431, или 11, как у CC956699, СC969507 и AF113918. Наименьшее значение РIC для праймеров локуса AF180355 было 0,30, где обнаружили всего 2 аллеля.

\section{2. Полиморфные микросателлитные локусы, использованные для оценки генети- ческих взаимосвязей между генотипами капусты кочанной (Brassica oleracea L.) (коллекция ФГБНУ Федерального научного центра овощеводства)}

\begin{tabular}{|c|c|c|c|c|}
\hline $\begin{array}{l}\text { Название маркера } \\
\text { в GenBank NCBI }\end{array}$ & $\begin{array}{l}\text { Гены с полиморфными микросателлит- } \\
\text { ными последовательностями }\end{array}$ & Мотив & $\begin{array}{l}\text { Число } \\
\text { аллелей }\end{array}$ & PIC \\
\hline AF051772 & Reproductive meristem gene 1 (REM1) mRNA & (gaa)5 & 3 & 0,81 \\
\hline $\mathrm{AF} 051772(2)$ & B3 domain-containing protein REM1 & (ct)6-1(ct)4-1(tcc)3 & 4 & 0,78 \\
\hline AF458409 & Deoxycytidine deaminase (DCTD1), mRNA & (aga) 6 & 5 & 0,90 \\
\hline AJ427337 & mRNA for calmodulin 1 (caml gene) & (ga) 5 & 3 & 0,61 \\
\hline BZ523957 & Genomic clone BOKAH45 & $(\operatorname{ttg}) 6$ & 5 & 0,86 \\
\hline CC956628 & $\begin{array}{l}\text { Brassica oleracea genomic clone BOIAA94, } \\
\text { genomic survey sequence }\end{array}$ & (tc) 5 & 2 & 0,50 \\
\hline CC956699 & $\begin{array}{l}\text { Brassica oleracea genomic clone BOIAB20, } \\
\text { genomic survey sequence }\end{array}$ & $(\mathrm{cac}) 9$ & 11 & 0,69 \\
\hline CC969431 & Genomic clone BOIAB19 & (ga) 6 & 13 & 0,61 \\
\hline CC969459 & Genomic clone BOIAB94 & $(\operatorname{cgg}) 5$ & 2 & 0,31 \\
\hline CC969497 & Genomic clone BOIAA26 & $(\operatorname{tgc}) 5$ & 2 & 0,83 \\
\hline CC969507 & Genomic clone BOIAB15 & (ct) 5 & 11 & 0,74 \\
\hline X94979 & mRNA for pollen coat protein & (atg) 5 & 2 & 0,44 \\
\hline AF241115 & Isolate HRI/CGN 5688 cauliflower gene & (at) 5 (ta) 6 & 6 & 0,51 \\
\hline X92955 & mRNA for pollen coat protein & (tttta)2(ata)7 & 3 & 0,57 \\
\hline AF180355 & Isolate $\mathrm{B} 265 \mathrm{ABI} 1$ protein $(\mathrm{ABI} 1)$ gene & (tc) 16 & 2 & 0,30 \\
\hline AF113919 & Phospholipase D2 (PLD2) gene & (at) $6(\mathrm{gt}) 5$ & 3 & 0,58 \\
\hline AF273844 & Thioredoxin-h-like protein 1 (THL1) mRNA & $(\mathrm{ctt}) 7$ & 4 & 0,73 \\
\hline AF230693 & Stearoyl-ACP desaturase (DELTA9-BO-1) gene & $(\mathrm{ctt}) 3(\mathrm{ct}) 6(\mathrm{cttg}) 6$ & 4 & 0,81 \\
\hline AF113918 & Phospholipase D1 (PLD1) gene & (ct) 7 (at) $7-1$ & 11 & 0,60 \\
\hline U67451 & $\begin{array}{l}\text { Brassica oleracea homeotic protein boilAP1 } \\
\text { (BoilAP1) mRNA }\end{array}$ & (at)9-1 & 6 & 0,81 \\
\hline AF241115(2) & Isolate HRI/CGN 5688 cauliflower gene & (ta)6-1 & 2 & 0,63 \\
\hline
\end{tabular}
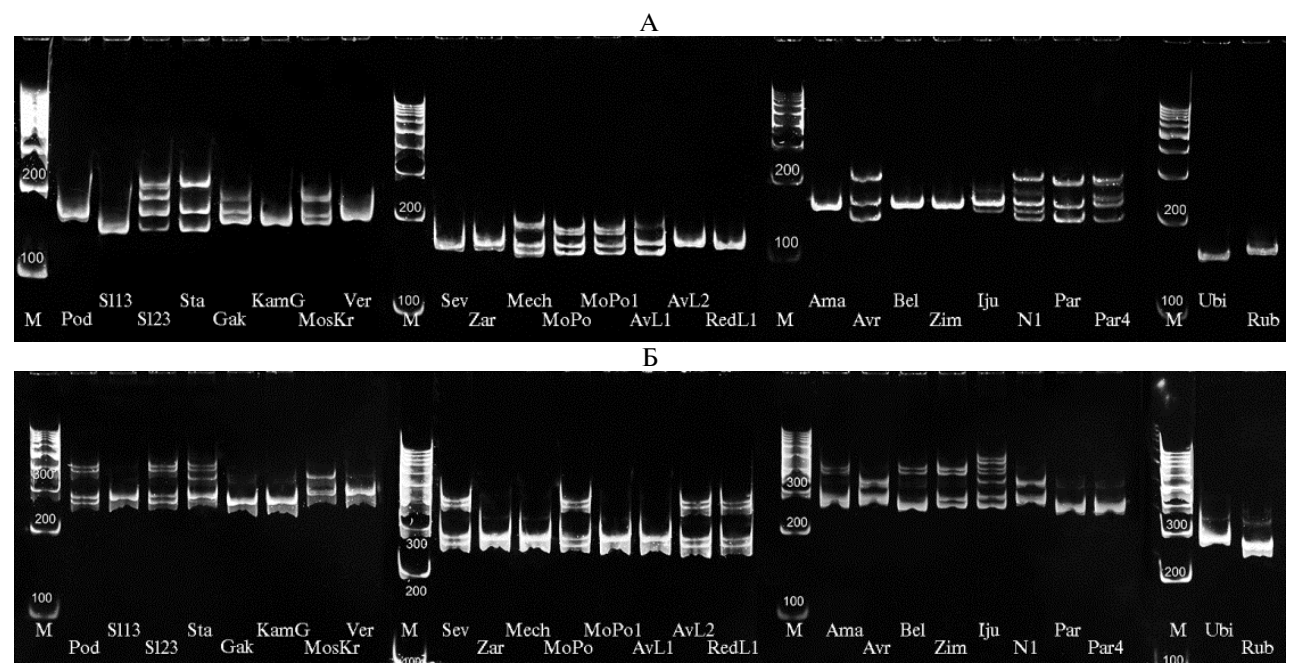

Рис. 1. Электрофореграммы продуктов ПЦР-амплификации микросателлитных локусов АF458409 (A) и BZ523957 (Б) у селекционных образцов капусты кочанной (Brassica oleracea L.) (коллекция ФГБНУ Федерального научного центра овощеводства). М - маркер молекулярных масс (GeneRuler100 bp plus DNA ladder, «Thermo Fisher Scientific», США). Расшифровку обозначений и описание образцов см. в таблице 1 . 
Рассчитанные данные для РІС в наших исследованиях согласуются со значениями, полученными для этих же маркеров другими авторами $\left(\chi^{2}=2,16\right.$ при $\left.\mathrm{p}=1,0\right)(11,12)$. Маркеры для локусов, которые при анализе показывали значение $\mathrm{PIC} \geq 0,5$, оказались эффективными при генетической дискриминации родственных генотипов (25). В итоге у изученных образцов с помощью этого набора маркеров мы выявили 76 \% полиморфизма.

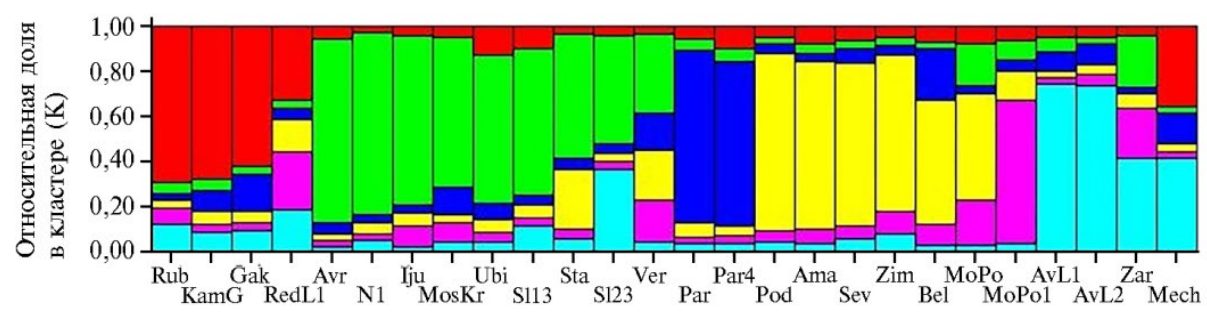

Рис. 2. Структура изученной выборки селекционных образцов капусты кочанной (Brassica oleracea L.) (коллекция ФГБНУ Федерального научного центра овощеводства), полученная с использованием программы STRUCTURE на основании байесовского анализа по шести кластерам $(\mathbf{K}=\mathbf{6})$. Расшифровку обозначений и описание образцов см. в таблице 1.

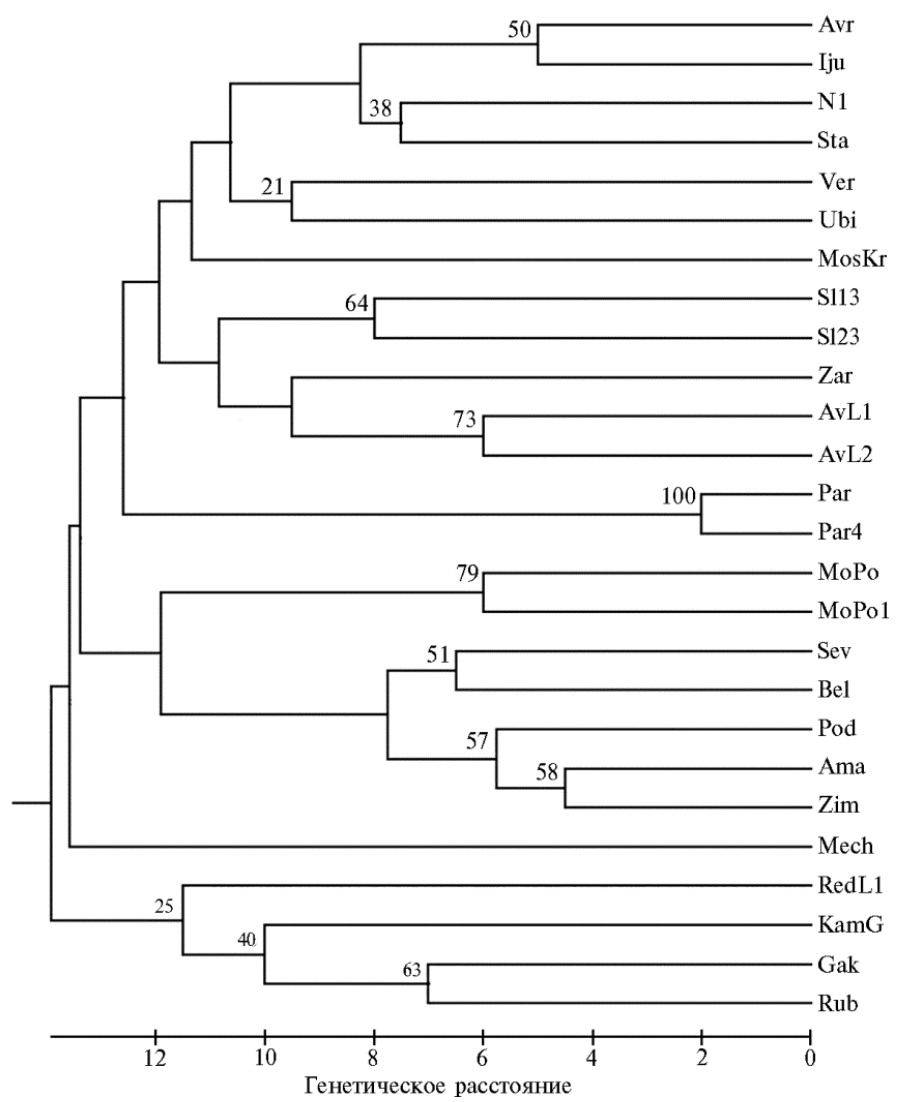

Рис. 3. UPGMA-дендрограмма генетического сходства между селекционными образцами капусты кочанной (Brassica oleracea L.) (коллекция ФГБНУ Федерального научного центра овощеводства), построенная на основе изменчивости микросателлитных локусов. Значения bootstrap получены для 1000 реплик. Расшифровку обозначений и описание образцов см. в таблице 1.

Результаты анализа данных в STRUCTURE показали, что все тестируемые образцы лучшим образом распределились по шести кластерам $(\Delta \mathrm{K}=2,05)$, где сгруппировались согласно происхождению (рис. 2). Подсчитанные генетические дистанции варьировали от 0,060 до 0,186 , причем 
наибольшее генетическое расстояние было отмечено между сортом Парус и гибридом Мечта F1. Образцы капусты Северянка F1, Белорусская 455, Подарок 2500, Амагер 611 и Зимовка 1474 голландской группы с происхождением из Северо-Западной Европы объединились в общий кластер (рис. 3). Высокое генетическое сходство сортов Амагер 611, Белорусская 455 и Подарок 2500 подтверждает то, что последний был получен посредством сложной гибридизации двух первых. Относительно новый гибрид Северянка F1 с улучшенными показателями качества и устойчивости к фузариозному увяданию, киле и бактериозу был создан при участии сортов Белорусская 455, Зимовка 1474 и Подарок 2500, отселектированных на Грибовской опытной станции. Сорт Белорусская 455 имел происхождение из Витебской области и был получен с помощью отбора наиболее скороспелых форм и районирован с 1943 года. Районированный в том же году и обладающий высокой продуктивностью позднеспелый сорт Московская поздняя 15 находился в отдельном подкластере, ближе к более поздним по спелости образцам, что объясняет его местное происхождение из сорта Пышкинская (26). Генетическая отдаленность этого сорта также подтверждается его принадлежностью к отдельному сортотипу в Среднерусской группе сортов. Сорт Парус с высокими показателями качества образовывал свой отдельный кластер, что доказывает его генетическую отдаленность от общей группы сортов и сложное происхождение от различных линий с хозяйственно ценными свойствами.

Сорта сортотипа Дитмарская ранняя происхождением из Центральной Европы (Июньская 3200, Стахановка 1513, Номер первый грибовский 147 и скороспелый гибрид Аврора F1, имеющий в родословной сорт Июньская 3200) сгруппировались в отдельный кластер. Все эти образцы обладали скороспелостью. Сорт Номер первый грибовский 147, районированный с 1943 года, был использован для создания сорта Июньская 3200, что также согласуется с его расположением на дендрограмме. Линии, выведенные из гибрида Аврора F1, образовали отдельный подкластер. Такое их расположение подтверждает, что линейный материал из гибрида может быть достаточно отдален от него генетически. Выведенные на Грибовской опытной станции и районированные в 1940 году традиционные среднеспелые сорта Слава грибовская 231 и Слава 1305, представляющие сортотип Слава, находились в отдельном подкластере.

Новый гибрид Зарница F1 среднераннего срока образовывал отдельную ветвь дендрограммы ближе к раннеспелым образцам, тогда как позднеспелый гибрид Мечта $\mathrm{F}_{1}$ сформировал кластер, который находился на расстоянии 0,123 от общей группы капуст белокочанных.

В отдельный подкластер внутри кластера капуст белокочанных объединились сорта капусты савойской. Все они относились к разным сортотипам, поэтому расположились генетически отдаленно друг от друга. Скороспелый сорт Юбилейная 2170 был получен в результате скрещивания капусты савойской Венская ранняя и сорта белокочанной капусты Номер первый 147. Новый сорт Московская кружевница среднераннего срока созревания с сильной пузырчатостью листа оказался наиболее генетически отдаленным от двух других сортов капусты савойской.

Традиционные сорта капусты краснокочанной Каменная головка 447 и Гако 741, выведенные на Грибовской опытной станции и районированные в 1943 году, относятся соответственно к сортотипам Эрфуртская и Гако, что подтверждается их генетической отдаленностью. В этом же кластере сгруппировались сорт Рубин и селекционная линия I3 424-17. Тради- 
ционные сорта хорошо адаптированы к местным условиям выращивания и представляют собой популяции, которые могут служить источниками генов для получения ценных линий, поскольку обладают генетической изменчивостью и пластичностью.

Нужно также отметить, что выведенные относительно недавно сорта Парус, Московская кружевница, гибриды Зарница F1 и Мечта F1 были достаточно отдалены от основных кластеров традиционных сортов. Кроме того, селекционные линии, выведенные из перспективных гибридов F1, в значительной мере отличались от изначальной формы, что позволяет контролировать процесс инбридинга при получении перспективных линий на основе гибрида с использованием ДНК маркеров.

В нашем исследовании относительно небольшой набор микросателлитных маркеров позволил классифицировать уникальные отечественные образцы капусты кочанной. В работе M.A. El-Esawi с соавт. (27) с использованием всего 12 микросателлитных локусов на 25 генотипах Brassica oleracea L., из которых 15 составляли капусты кочанные, было выявлено 75,7 \% полиморфизма, что согласуется с полученными нами данными.

Несмотря на значительные достижения в генетике капустных культур, основные исследования, как правило, сконцентрированы на изучении устойчивости к патогенам (28-30), времени цветения $(31,32)$, морфологических показателей кочана (33), растрескивании кочана $(34,35)$, тогда как сведения по генетической идентификации сортов капусты кочанной, принадлежащих к различным группам спелости, практически отсутствуют. На основе генетической оценки изученных образцов мы выделили две основные группы генотипов капусты белокочанной: раннего срока созревания (кластер с образцами Аврора F1, Июньская, Номер первый грибовский 147, Стахановка 1513) и позднего срока созревания (Московская поздняя 15, Северянка $F_{1}$, Белорусская 455, Амагер 611 и Зимовка 1474). Генотипы савойской разновидности в целом обладали большей скороспелостью, что может объяснить их близкое генетическое расположение к группе более скороспелых образцов. Из них сорт Вертю 1340 относился к наиболее позднеспелым с периодом созревания около 130 сут, тогда как поздние генотипы капусты белокочанной могут созревать более 140 сут.

В силу того, что морфологические признаки и характеристики известных сортов могут быть подвержены воздействию факторов внешней среды, которые вызывают фенотипическую изменчивость и делают оценку сортовых качеств затруднительной, ДНК маркеры оказываются единственным инструментом для точного определения, поддержания и сохранения необходимых для дальнейшей селекции генотипов (36). Селекционные образцы, принадлежащие к различным группам спелости и ценным отечественным сортотипам и пригодные для выращивания во всех регионах России, могут быть определены и отобраны на основании результатов ДНКанализа с использованием набора известных SSR маркеров.

Таким образом, SSR маркеры показали эффективность в выявлении генетической изменчивости у 24 генотипов капусты кочанной, среди которых были близкие по происхождению и принадлежащие к одному сортотипу. Результаты ДНК-анализа подтвердили все родственные связи среди традиционных сортов и новых гибридов. Следовательно, установленная генетическая основа изученных образцов может быть определяющей для возможных комбинационных скрещиваний при получении новых селекционных форм. Результаты SSR-анализа и данные о генетических дистанциях предоставляют информацию для отбора селекционного материала, контроля комбинаций среди форм различных групп спелости с признаками 


\section{ЛИТЕРАТУРА}

1. Chepkemoi J. The world leaders in cabbage production. WorldAtlas, 2017. Режим доступа: worldatlas.com/articles/the-world-leaders-in-cabbage-production.html. Дата обращения: 15.03.2020.

2. Novotny C., Schulzova V., Krmela A., Hajslova J., Svobodova K., Koudela M. Ascorbic acid and glucosinolate levels in new czech cabbage cultivars: effect of production system and fungal infection. Molecules, 2018, 23(8): 1855 (doi: 10.3390/molecules23081855).

3. Лизгунова Т.В. Культурная флора СССР. Том 11. Капуста. Л., 1984.

4. Formisano G., Roig C., Esteras C., Ercolano M.R., Nuez F., Monforte A.J., Pico M.B. Genetic diversity of Spanish Cucurbita pepo landraces: an unexploited resource for summer squash breeding. Genetic Resources and Crop Evolution, 2012, 59(6): 1169-1184 (doi: 10.1007/s10722-0119753-y).

5. Collard B.C.Y, Mackill D.J. Marker-assisted selection: an approach for precision plant breeding in the twenty-first century. Philosophical Transactions of the Royal Society B: Biological Sciences, 2008, 363(1491): 557-572 (doi: 10.1098/rstb.2007.2170).

6. Guichoux E., Lagache L., Wagner S., Chaumeil P., Léger P, Lepais O., Lepoittevin C., Malausa T., Revardel E., Salin F., Petit R.J. Current trends in microsatellite genotyping. Molecular Ecology Resources, 2011, 11(4): 591-611 (doi: 10.1111/j.1755-0998.2011.03014.x).

7. Lowe A.J., Moule C., Trick M., Edwards K.J. Efficient large-scale development of microsatellites for marker and mapping application in Brassica crop species. Theoretical and Applied Genetics, 2004, 108(6): 1103-1112 (doi: 10.1007/s00122-003-1522-7).

8. Márquez-Lema A., Velasco L., Pérez-Vich B. Transferability, amplification quality, and genome specificity of microsatellites in Brassica carinata and related species. Journal of Applied Genetics, 2010, 51(2): 123-131 (doi: 10.1007/BF03195720).

9. Thakur A.K., Singh K.H., Singh L., Nanjundanet J., Khan Y.J., Singh D. SSR marker variations in Brassica species provide insight into the origin and evolution of Brassica amphidiploids. Hereditas, 2018, 155(6): 1-11 (doi: 10.1186/s41065-017-0041-5).

10. Raza A., Mehmood S.S., Ashraf F., Khan R.S.A. Genetic diversity analysis of Brassica species using PCR-based SSR markers. Gesunde Pflanzen, 2019, 71(1): 1-7 (doi: 10.1007/s10343-018-0435-y).

11. Tonguc M., Griffiths P.D. Genetic relationships of Brassica vegetables determined using database derived sequence repeats. Euphytica, 2004, 137(2): 193-201 (doi: 10.1023/B:EUPH.0000041577.84388.43).

12. Louarn S., Torp A.M., Holme I.B., Andersen S.B., Jensen B.D. Database derived microsatellite markers (SSRs) for cultivar differentiation in Brassica oleracea. Genetic Resources and Crop Evolution, 2007, 54(8): 1717-1725 (doi: 10.1007/s10722-006-9181-6).

13. Saxena B., Kaur R., Bhardwaj S.V. Assessment of genetic diversity in cabbage cultivars using RAPD and SSR markers. Journal of Crop Science and Biotechnology, 2011, 14(3): 191-196 (doi: 10.1007/s12892-011-0018-2).

14. Zhu S., Zhang X., Liu Q., Luo T., Tang Z., Zhou Y. The genetic diversity and relationships of cauliflower (Brassica oleracea var. botrytis) inbred lines assessed by using SSR markers. PLoS ONE, 2018, 13(12): e0208551 (doi: 10.1371/journal.pone.0208551).

15. Артемьева А.М., Клоке Э., Чесноков Ю.В. Анализ филогенетических связей вида Brassica oleracea L. (капуста огородная). Информационный вестник ВОГиС, 2009, 13(4): 759-771.

16. Izzah N.K., Lee J., Perumal S., Park J.Y., Ahn K., Fu D., Kim G.-B., Nam Y.-W., Yang T.-J. Microsatellite-based analysis of genetic diversity in 91 commercial Brassica oleracea L. cultivars belonging to six varietal groups. Genetic Resources and Crop Evolution, 2013, 60(7): 1967-1986 (doi: 10.1007/s10722-013-9966-3).

17. Shapturenko M., Khotyleva L., Vakula S., Jakimovich A.V., Zabara Yu.M., Khotyleva L.V. Informative EST-SSR markers for genotyping and intraspecific differentiation of Brassica oleracea var. capitata L. Vavilov Journal of Genetics and Breeding, 2016, 20(1): 51-56.

18. Чесноков Ю.В., Артемьева А.М. Оценка меры информационного полиморфизма генетического разнообразия. Сельскохозяйственная биология, 2015, 50(5): 571-578 (doi: 10.15389/agrobiology.2015.5.571rus).

19. Pritchard J.K., Stephens M., Donnelly P. Inference of population structure using multilocus genotype data. Genetics, 2000, 155(2): 945-959.

20. Earl D.A., vonHoldt B.M. STRUCTURE HARVESTER: a website and program for visualizing STRUCTURE output and implementing the Evanno method. Conservation Genetics Resources, 2012, 4(2): 359-361 (doi: 10.1007/s12686-011-9548-7).

21. Peakall R., Smouse P.E. GenAlEx 6.5: genetic analysis in Excel. Population genetic software for teaching and research-an update. Bioinformatics, 2012, 28(19): 2537-2539 (doi: 10.1093/bioinformatics/bts460).

22. Nei M. Genetic distance between populations. American Naturalist, 1972, 106(949): 283-392 (doi: 
10.1086/282771).

23. Nei M. Estimation of average heterozygosity and genetic distance from a small number of individuals. Genetics, 1978, 89(3): 583-590.

24. Tamura K., Peterson D., Peterson N., Stecher G., Nei M., Kumar S. MEGA5: molecular evolutionary genetic analysis using maximum likelihood, evolutionary distance, and maximum parsimony methods. Molecular Biology and Evolution, 2011, 28(10): 2731-2739 (doi: 10.1093/molbev/msr121).

25. DeWoody J.A., Honeycutt R.L., Skow L.C. Microsatellite markers in white-tailed deer. Journal of Heredity, 1995, 86(4): 317-319 (doi: 10.1093/oxfordjournals.jhered.a111593).

26. Елена Михайловна Попова. Ученый, селекционер. Основоположник научной отечественной селекции по капустным культурам. Научное наследие - воспоминания, развитие научных идей /Под ред. В.Ф. Пивоварова. М., 2007.

27. El-Esawi M.A., Germaine K., Bourke P., Malone R. Genetic diversity and population structure of Brassica oleracea germplasm in Ireland using SSR markers. Comptes Rendus Biologies, 2016, 339(3-4): 130-140 (doi: 10.1016/j.crvi.2016.02.002).

28. Peng L., Zhou L., Li Q., Wei D., Ren X., Song H., Mei J., Si J. Qian W. Identification of quantitative trait loci for clubroot resistance in Brassica oleracea with the use of Brassica SNP microarray. Frontiers in Plant Science, 2018, 9(822): 1-8 (doi: 10.3389/fpls.2018.00822).

29. Kifuji Y., Hanzawa H., Terasawa Y., Ashutosh, Nishio T. QTL analysis of black rot resistance in cabbage using newly developed EST-SNP markers. Euphytica, 2013, 190(2): 289-295 (doi: 10.1007/s10681-012-0847-1).

30. Mei J.Q., Ding Y.G., Lu K., Wei D.Y., Liu Y., Disi J.O., Li J., Liu L., Liu S., McKay J., Qian W. Identification of genomic regions involved in resistance against Sclerotinia sclerotiorum from wild Brassica oleracea. Theoretical and Applied Genetics, 2013, 126(2): 549-556 (doi: 10.1007/s00122-012-2000-x).

31. Okazaki K., Sakamoto K., Kikuchi R., Saito A., Togashi E., Kuginuki Y., Matsumoto S., Hirai M. Mapping and characterization of FLC homologs and QTL analysis of flowering time in Brassica oleracea. Theoretical and Applied Genetics, 2007, 114(4): 595-608 (doi: 10.1007/s00122006-0460-6).

32. Uptmoor R., Schrag T., Stützel H., Esch E. Crop model based QTL analysis across environments and QTL based estimation of time to floral induction and flowering in Brassica oleracea. Molecular Breeding, 2008, 21(2): 205-216 (doi: 10.1007/s11032-007-9121-y).

33. Lv H., Wang Q., Zhang Y., Yang L., Fang Z., Wang X., Liu Y., Zhuang M., Lin Y., Yu H., Liu B. Linkage map construction using InDel and SSR markers and QTL analysis of heading traits in cabbage. Molecular Breeding, 2014, 34(1): 87-98 (doi: 10.1007/s11032-014-0019-1).

34. Pang W., Li X., Choi S.R., Nguyen V.D., Dhandapani V., Kim Y.Y., Ramchiary N., Kim J.G., Edwards D., Batley J., Na J., Kim H.R., Lim Y.P. Mapping QTLs of resistance to head splitting in cabbage (Brassica oleracea L. var. capitata L.). Molecular Breeding, 2015, 35(5): 1-12 (doi: 10.1007/s11032-015-0318-1).

35. Su Y., Liu Y., Li Z., Fang Z., Yang L., Zhuang M., Zhang Y. QTL analysis of head splitting resistance in cabbage (Brassica oleracea L. var. capitata) using SSR and InDel makers based on whole-genome re-sequencing. PLoS ONE, 2015, 10(9): e0138073 (doi: 10.1371/journal.pone.0138073).

36. Korir N.K., Han J., Shangguan L., Wang C., Kayesh E., Zhang Y., Fang J. Plant variety and cultivar identification: advances and prospects. Critical Reviews in Biotechnology, 2013, 33(2): 111 125 (doi: 10.3109/07388551.2012.675314).

ФГБНУ Федеральный научный иентр овощеводства,

143080 Россия, Московская обл., Одинцовский р-н, пос. ВНИИССОК, ул. Селекционная, 14,

e-mail: arthurdom@inbox.ru $₫$, lyuda_bondareva@mail.ru,

pivovarov@vniissok.ru

Sel'skokhozyaistvennaya biologiya [Agricultural Biology], 2020, V. 55, № 5, pp. 890-900

\section{ASSESSMENT OF GENETIC DIVERSITY AMONG HEADED CABBAGE (Brassica oleracea L.) ACCESSIONS BY USING SSR MARKERS}

\section{A.S. Domblides $\bowtie$, L.L. Bondareva, V.F. Pivovarov}

Federal Research Center for Vegetable Growing, 14, ul. Selektsionnaya, pos. VNIISSOK, Odintsovskii Region, Moscow Province, 143080 Russia, e-mail arthurdom@inbox.ru (corresponding author $₫$ ), lyuda_bondareva@mail.ru, pivovarov@vniissok.ru

ORCID:

Domblides A.S. orcid.org/0000-0002-5617-9498

Bondareva L.L. orcid.org/0000-0002-0912-5913

Pivovarov V.F. orcid.org/0000-0001-9522-8072 


\section{Abstract}

Out of all cole crops in Russian Federation traditional cultivars and hybrids of headed cabbage B. oleracea $\mathrm{L}$. convar. capitata $(\mathrm{L}$.) are the most widespread. The classification of breeding material with the use of DNA markers enables to find out valuable genotypes and to detect genetic relationships among them in order to develop genetically distinguishing breeding forms. Microsatellite (SSR) markers are known to have been broadly used for genetic identification and genotyping in crops. These markers have shown their efficiency to reveal the polymorphism among varieties, cultivars and within cultivars in B. oleracea L. In the present work we have estimated for the first time the genetic relationship among local accessions of headed cabbage on the basis of SSR-loci polymorphism. The goal of the work was to reveal genetic relationship between breeding accessions of $B$. oleracea $\mathrm{L}$. convar. capitata (L.) Alef. var. capitata L. f. alba, var. capitata L. f. rubra, and var. sabauda L. based on DNA typing and genetic classification using SSR markers, and to compare DNA data of studied genotypes with defined cabbage varietal and maturity groups. Twenty-four breeding accessions of headed cabbage including red and Savoy varieties from collection of Federal Research Center for Vegetable Growing (FRCVG) and also developed at FRCVG were involved. Genomic DNA was extracted from young plant leaves at 2-3 leaf stage with DNA extraction kit Sorb-GMO (Syntol, Russia). Final DNA purity and concentration were identified with the SmartSpec Plus spectrophotometer (Bio-Rad, USA). Twenty-one microsatellite loci with known primer sequences were chosen to perform SSR analysis. The amplification was run in C1000 Touch thermocycler (Bio-Rad, USA). PCR products were separated in a $6 \%$ polyacrylamide sequencing gel with the use of Sequi-Gen GT electrophoresis system (Bio-Rad, USA). The fragments sizes were detected in comparison with molecular weight markers GeneRuler100 bp plus DNA ladder (Thermo Fisher Scientific, USA). The digital images of electrophoregrams were analyzed with Image Lab 3.0 software (Bio-Rad, USA). STRUCTURE 2.3.4 (https://web.stanford.edu/group/pritchardlab/home.html) software was used to study population structure. The genetic distances were calculated using GenAlEx 6.5 software for Microsoft Excel by Nei's method. To construct the UPGMA dendrogram the algorithm of MEGA 5.2 program was used. As a result of analysis 103 alleles were obtained with an average 4.9 alleles per locus. PCR product sizes were between 130 and $410 \mathrm{bp}$. The PIC value varied from 0.3 to 0.9 . Population analysis revealed six clusters to distribute all breeding accessions. Calculated Nei's genetic distances varied from 0.060 to 0.186 . The UPGMA deprogram constructed on distances matrix reflected the origin of cabbage accessions taken. Thus, cultivars Belorusskaya 455, Podarok 2500, Amager 611 and Zimovka 1474 originated from Northwestern Europe were joined into one cluster, there was also hybrid Severiynka F1 developed with the use of these cultivars. Early-maturing varietal group Ditmarskaya Raniya represented by cultivars Ijunskaya 3200, Stakhanovka 1513, Nomer Perviy Gribovskiy 147 formed a separate cluster which also included an early-maturing hybrid Avrora F1 being of a partial origin from Ijunskaya 3200. Two breeding lines obtained from Avrora F1 were genetically distant and disposed in another subcluster. Cultivars Slava 1305 and Slava 231 belonging to the separate varietal group Slava formed a branch of the dendrogram. Cultivar Parus and hybrids Zarnitsa F1, Mechta F1 developed relatively recently were disposed distantly from other accessions. Moscovskaya pozdnyaya 15 a local cultivar formed its own branch of the dendrogram. Three cultivars of Savoy cabbage were grouped together with sufficient genetic distance between each other, where a new early-maturing cultivar Moskovskaya kruzhevnitsa was more distant from others. The group of red cabbage accessions situated distantly from other clusters with great difference inside the group. The obtained results based on SSR marker variation were in accordance with data on the origin of headed cabbage accessions confirming that they belong to defined varietal and maturity groups. This provides information for nearest breeding program for new cabbage breeding forms.

Keywords: Brassica oleracea L., headed cabbage, SSR markers, genetic identification, cultivar genotype polymorphism, varietal group. 